50 years or more, and there were 8,000 persons between the ages of 40 and 50 years. The increase in the total number of the blind was not, in his opinion, due to any real increase in numbers, but to more complete registration, longer life, and increased inducements to blind people to register at the present time. The total number of blind children between the ages of 5 and 16 years had fallen since the year 1925 from 3,104 to 1,916 . Only $2 \cdot 95$ per cent. of the 8,700 new cases which were registered in the year ending March 31, 1937, were under the age of 16 years, and about 89 per cent. were over the age of 40 years.

As is well known, the first clause of this Bill provides for a reduction of the age for the receipt of old age pensions in the case of blind persons from 50 to 40 years of age.

No one will grudge the blind the amelioration of their lot which is fore-shadowed in this Bill, if, as we all hope, it passes on to the Statute Book.

The age of 40 years was chosen because of the difficulty of teaching a trade after that age. A lower limit would diminish the incentive of blind persons to attempt to earn their daily bread.

The only regrets that we can see will be those of the blind who have gone before. We fancy we see "Poluphloisboisterous" Homer congratulating the first of the new beneficiaries under the Act who is conveyed across the Styx and commenting on how times are changed. He never received 10 drachmae a week.

\title{
ABSTRACTS
}

\section{I.-OPTIC NERVE}

(1) Behr, Carl (Hamburg).-New anatomical facts on papilloedema. (Neue anatomische Befunde bei Staungspapille). Arch.f. Ophthal., Vol. CXXXVII, p. 1.

(1) In this contribution to the pathogenesis of papilloedema of intracranial origin Behr demonstrates in anatomical preparations, embedded in gelatine so as to avoid shrinkage and the formation of artefacts, the presence of spaces or small cavities between the nerve fibre bundles along the whole length of the optic nerve from the disc to the optic canal: the nerve fibres separated from each other or pressed together in such a way as to indicate that these spaces must have been caused by a collection of fluid under pressure between the nerve fibres intra vitam. He lays emphasis on the fact that this oedema is intrafascicular, and is not present in or under the pial sheath, septa or in the axial connective tissue strand; 
the oedema causing the swelling of the papilla has no relation whatever to the central vessels of the disc or their perivascular tissue.

The distribution of the spaces in the optic nerve, which roughly corresponds with the defects in the visual fields, depends on the duration and intensity of the papilloedema; in the initial stages they appear only in the nerve fibres immediately under the pial sheath, but as the process spreads they extend more and more towards the axis of the nerve and eventually throughout it.

This condition, according to his views, is one of stasis due to obstruction to the flow of the fluid in the nerve fibres from the papilla towards the cranial cavity by the increased intracranial pressure. It is also seen in extra-neural tumours of the orbit.

It is contended that the anatomical facts here described disprove the theory that the subarachnoid fluid is under increased pressure and presses along the perivascular spaces of the central vessels into the optic disc; there is no evidence of obstruction to the blood flow in the retinal vein in its passage through the subarachnoid space, while the changes in the pressure and diameters of the central vessels, which have been cited as the cause of papilloedema, are easily explained by a stasis of the intrafascicular fluid.

Thos. SNOWBal.L.

(2) Sobanski, J. (Warsaw).- The value of dynamometric investigations in determining the pathogenesis of papilloedema. (Der Wert dynamometrischer Untersuchung für die Erklärung der Entstehung der Stauungspapille). Arch.f. Ophthal., Vol. CXXXVII, p. 84.

(2) Sobanski's researches on papilloedema were partly clinical, in which he made dynamometric estimations of the pressure in the central retinal vessels and a comparison of the blood pressure with that of the cerebro-spinal fluid : partly experimental, to discover by compression of the retrobulbar portion of the optic nerve the position in the nerve at which the action of the subarachnoid fluid on the blood pressure in the central vein takes place. From his experiments it was shown that papilloedema developed only on compression of the part of the nerve containing the central retinal vessels.

His investigations by dynamometric measurements on the disturbances of the retinal circulation in increased intracranial pressure proved that papilloedema does not supervene until the ratio of the pressure in the central vein to the diastolic pressure in the artery exceeds $1: 1.5$, the swelling of the papilla increasing with further rise in the ratio.

This disturbance in the normal relation of the pressure in the central vein and the artery is the most important factor in the 
pathogenesis of papilloedema, and is due to obstruction to the circulation in the central vein from the eye, this obstruction taking place in the part of the nerve carrying the central vessels.

Of secondary importance is the obstruction to the return flow of the tissue fluid from the eye along the optic nerve, while the state of the intra-ocular pressure, the size of the papilla and other factors have an indirect effect.

This problem can be solved only by dynamometric estimations added to experiment, not by pathological-anatomical investigations alone.

Thos. SNOWBALL.

(3) Much, Viktor (Lucerne).-Amyl nitrite in the treatment of diseases of the optic nerve. (Das Amylnitrit in der Behandlung von Erkrankungen des Opticus). Zeitschr.f. Augenheilk., Vol. LXXXIX, p. 58, 1936.

(3) Much reports favourably on the effects of amyl nitrite in five cases of toxic amblyopia (tobacco and alcohol), one case of retrobulbar neuritis in disseminated sclerosis, one case of renal neuro-retinitis and in one case of post-neuritic atrophy. The amyl nitrite was inhaled in doses of $2-4$ drops. In five cases of toxic amblyopia and the case of post-neuritic atrophy recovery was complete. The two other cases were greatly improved.

ARNOLD SORSBY.

\section{II.-RETINA}

(1) Messinger, Harry C. and Clarke, B. Earl (Providence, R.I.). -Tumours in the tuberous sclerosis. Arch. of Ophthal., July, 1937.

(1) Retinal involvement in tuberous sclerosis was first described by van der Hoeve in 1921, and the disease itself by Bourneville in a series of articles published from 1880 to 1898 . It consists in a rare form of cerebral sclerosis, associated during life with mental deficiency, epilepsy and adenoma sebaceum, distributed in butterfly fashion on the face. The syndrome is variable however, and there may be multiple tumours of mixed undifferentiated cells, in the heart, kidney, spleen and eye, as well as in the brain. A family history of developmental defects and psychopathic trends is common. The retinal tumours occur as oval or circular, white or grey areas, with an average diameter of about one-half that of the disc. The tumours are occasionally larger and nodular, extending into the vitreous usually at or near the disc. In the brain the typical, 
multiple small tumours are in the cortex, but there are often others, projecting into the ventricles and sometimes causing papilloedema. Messinger and Clarke's case occurred in a man, aged 20 years, who had had convulsive seizures since the age of four, was afflicted with adenoma sebaceum and died from broncho-pneumonia. Ophthalmoscopically, his right eye was found to contain a white nodular tumour extending forwards $5 \mathrm{D}$. and obscuring the disc. Postmortem there were multiple tumours of the brain, rhabdomyoma of the heart, and lipomata of the kidneys and adenoma sebaceum. The tumour in the eye involved all the layers of the retina and invaded part of the optic nerve. Its central portion was irregularly ossified. The cells of the tumour varied in size and shape, and their boundaries were indistinct, suggesting a syncitium. The sections were examined by Ida Mann who suggested that the tumour had arisen during stage 2 of retinal differentiation (from the sixth week to the third month) from glia cells of the inner neuroblastic layer, with a few undifferentiated amacrine and ganglion cells included. The authors conclude from these observations and the descriptions in the literature, that the growths in the brain and other organs are haematomata rather than true tumours.

F. A. W-N.

(2) Scheyhing, H. (München).-Cure of a glioma retinae by X-rays. (Heilung eines Netzhautglioms durch Röntgenbestrahlung). Klin. Monatsbl.f. Augenheilk., Vol. XCVIII, p. 756, 1937.

(2) Scheyhing describes the successful treatment of a retinal glioma by $\mathrm{X}$-rays in increasing doses over several years. A cataract developed which was removed and the patient retained good vision. The companion eye had been removed for advanced glioma retinae. Details of dosage are given.

D. R. Campbell.

(3) Vogt, A. (Zürich).-Histological findings in another case of relatively recent (senile-myopic) retinal detachment. (Histologischer Befund eines weiteren Falles von relativ frischer spontaner (senil-myoper) Netzhautablösung). Klin. Monatsbl. f. Augenheilk., Vol. XCVIII, p. 735, 1937.

(3) Vogt describes the histology of an eye of a patient, aged 72 years, who died 37 days after the onset of a retinal detachment. A previous clinical examination had shown a hole at the periphery and an operation had been performed which had not succeeded in closing the hole. There was marked thinning of the retina in the region of the hole and the torn away piece appeared to have been pulled off by the neighbouring vitreous to which it was still adherent. 
Although the eye was myopic the author considers that the centripetal action of the vitreous was the primary cause of the detachment. since the whole of the vitreous was massed forwards close behind the lens. There was no evidence of inflammatory changes in the vitreous.

D. R. CAMPBELl.

\section{III.-CORNEA}

(1) MacMillan, J. A. and Cone, Wm. (Montreal).-The prevention and treatment of keratitis neuroparalytica by closure of the lachrymal canaliculi. Canadian Med. Assoc. Jl., October, 1937.

(1) MacMillan and Cone read this paper at the 30th meeting of the Society of Neurological Surgeons, at Montreal, on May 31, 1937, and at the meeting of the Canadian Medical Association, at Ottawa, in June, 1937. They point out that the present methods of treatment of neuroparalytic keratitis, though effective, are cumbersome. Their studies have convinced them that although the cornea is anaesthetic it is the diminished tear secretion which is the primary factor in these corneal lesions.

They report a case where a satisfactory result was obtained by closing the canaliculi and maintained over a period of five months, with incidentally an improvement in vision from 6/30 to 6/15.

The canaliculi were closed by electro-coagulation. Sensation being lost, no anaesthetic is required; but the canals tend to become patent again after a few days. When the canaliculus is slit with the actual cautery it is closed permanently.

A bibliography of nine items is appended.

R. R. J.

(2) Jese, L. (Ljubljana).-Keratitis nummularis. (Ueber Keratitis nummularis). Klin. Monatsbl.f. Augenheilk., Vol. XCVI, p. 219, 1936.

(2) Jese discusses 102 cases of keratitis nummularis he has seen since 1932, mostly in agricultural workers. On an average the number of lesions is 10 to 15; only four patients had a single nodule, and seven two nodules. The solitary nodules were always peripheral. In size the nodules ranged from being first visible with oblique illumination to round areas $3 \mathrm{~mm}$. in diameter; the peripheral nodules were always the largest. There was some plan in their arrangement and they were situated in the anterior third of the parenchyma. They were not sharply demarcated and the 
slit-lamp revealed the characteristic white dots in the epithelium. The fresh lesion pushes the epithelium forward; later on this flattens out leaving a glistening, facetted surface with. a yellow centre. Superficial vascularisation was common, deep vascularisation and also iritis uncommon, though hyperaemia of the iris was present in 31 cases. There is no treatment besides atropine and symptomatic measures. The author holds that the conditions is allied to the herpes group.

ARNOLD SORSBY.

(3) Vogt, A. (Zürich).-Keratoconus lines and their anatomical basis. (Die Keratoconus Linien der Kegelspitze und ihre anatomische Grundlage). Klin. Monatsbl.f. Augenheilk., Vol. XCVIII, p. 577, 1937.

(3) Vogt records his observations, by slit-lamp and histological investigation, on the condition of keratoconus. Three types of opacity are present-the most superficial is in Bowman's layer, the second consisting of striae in the deep parenchyma and the third are tears in Descemet's membrane. The author discusses the origin of these changes.

\section{R. CAMPBEll.}

\section{IV.-MEDICAL OPHTHALMOLOGY}

(1) Testa (Turin).-Changes of the optic foramina in oxycephaly. (Oxicefalia ed alterazione dei forami ottici). Rass. Ital. d'Ottal., March-April, 1937.

(1) Testa gives an account of a case of advanced oxycephaly which he has followed for some years; when first seen the boy had $6 / 10$ in the right eye; hand movements in the left. The left optic foramen was shown by the radiograph to be reduced to a narrow slit; the right also was not so large as in a normal skull. In 1936 the boy was again examined and the left eye was found to be totally blind, but the right eye still kept an acuity of $6 / 10$.

The author discusses the possibility of surgical interference. The optic canal may be reached either from the orbit or from the cavity of the skull; in either case the roof of the canal must be removed to release the nerve from the pressure. The chief difficulty is that in most cases the nerve has been hopelessly damaged before the condition is recognised as serious, by those in charge of the child.

HaRold Grimsdale. 
(2) Kyrieleis, W. (Hamburg).-Fundus changes in lymphogranulomatosis. (Ueber Augenhintergrundsveränderungen bei Lymphogranulomatose). Zeitschr. f. Augenheilk., Vol. LXXXIX, p. 183, 1936.

(2) Kyrieleis recalls that no fundus changes have been reported in Hodgkin's disease. Reviewing doubtful instances recorded in the literature, he holds that there are no characteristic fundus lesions. This is borne out by a case of Hodgkin's disease reported in full. Fundus changes did appear in this case six days before death. Clinically and histologically these were the changes found in any severe anaemia. The characteristic histological picture of Hodgkin's disease could not be found in the retina or around its blood vessels

ARNOLD SORSBY.

(3) Prewitt, L. H. (Ottumwa, Iowa).-Retinal detachment due to Allergy. Arch. of Ophthal., July, 1937.

(3) Prewitt's patient was a man, aged 62 years, with myopic astigmatism and some lens opacities. At his first examination he complained of blurred vision in the left eye and was found to have an early retinal detachment. He also had some nodular swellings on his body which he said were due to eating certain food.

Complete rest for two weeks and the application of pads and bandages brought about reposition of the retina. Three months later the condition recurred and a large detachment developed which did not go back. Four months later an early detachment developed in the right eye and was cured by rest, to recur in another four months and again be cured by rest. Two months later still the lens having become more opaque, was extracted intracapsularly and advantage was taken of his being in hospital to apply intradermal tests. He gave positive reactions to a large number of different substances and a diet was planned which omitted the offending allergens with the result that he remained free from attacks over a period of about four years, except on one occasion when a flare up occurred following a "Thanksgiving" dinner at which he ate turkey's liver. 


\section{V.-MISCELLANEOUS}

(1) Fuchs, A. (Wien).-Leprosy bacilli in eyes with a normal clinical appearance. (Ueber Leprabazillen in klinisch normal erscheinenden Augen). Klin. Monatsbl. f. Augenheilk., Vol. XCVIII, p. 728, 1937.

(1) Fuchs investigated the eyes of three patients suffering from leprosy. In life, they had been free from ocular symptoms but histologically the following changes were found:-

1. Inflammatory areas in the episclera, with bacilli in the periphery of the cornea.

2. Numerous bacilli and lepra cells in the ciliary body and ora serrata-but without inflammatory reaction in these tissues.

He considers that the bacilli probably enter the eyeball by the blood stream and give rise to these changes long before the more obvious inflammation of the lids appears.

D. R. CAM PBELL.

(2) Tertsch, R. (Vienna).-Another case of periarteritis nodosa with changes on the arteries of the extra-ocular muscles. (ein weiteres Fall von Periarteritis nodosa mit Veränderungen an den Arterien der äussern Augenmuskeln). Zeitschr. f. Augenheilk., Vol. LXXXVII, p. 294, 1935.

(2) Tertsch records another case with ocular involvement in this highly fatal infection. In his case a systematic post-mortem examination revealed the typical periarterial infiltration in three of the extra-ocular muscles. In contrast to other reported cases with ocular involvement, the globes themselves were unaffected.

\section{ARNOLD SORSBY.}

(3) Muiller, H. K. (Berlin).-The mechanics of the exfoliation of the lens capsule in capsular glaucoma. (Zur Mechanik der Abschilferung der Linsenkapsel bei Glaukoma capsulare). Klin. Monatsbl. f. Augenheilk., Vol. XCVIII, p. 653, 1937.

(3) Müller describes an interesting case which proves that in capsular glaucoma the exfoliation of the lens capsule is due to the friction of the iris on the anterior surface of the lens. A preliminary iridectomy had been performed on the left eye some time previously. In both eyes there was a greyish white ring of opacity in the anterior lens capsule, which corresponded to the customary position of the edge of the pupil. In the left eye this was absent in the area corresponding to the coloboma. Fine white particles, which were probably lens matter, could be seen adherent to the zonular fibres. The author emphasizes the importance of prophylactic 
treatment by the use of miotics or mydriatics in preventing a constant position of the pupil, and suggests that capsular glaucoma may be more common than is usually supposed. Indeed, Hörven found signs of exfoliation of the lens capsule in 85 per cent. of his cases of glaucoma simplex.

D. R. CAMPBELl.

(4) Streiff, E. B. (Genf).- The action of syntropan on normal and glaucomatous eyes. (Wirkung des Syntropans im normalen und glaukomatösen Augen). Klin. Monatsbl.f. Augenheilk., Vol. XCVIII, p. 504, 1937.

(4) Streiff describes the action of a 5 per cent. solution of syntropan (Hoffman-la-Roche). It stings the eye slightly and produces maximum mydriasis in 20-30 minutes. Usually the pupil begins to contract again in 45-60 minutes. The effect on accommodation is $0.5-0.75$ dioptres and lasts about the same time. The action of the drug was compared with that of 2 per cent. cocaine and 2 per cent. homatropine. It was a better mydriatic than the former and almost equal to the latter. 2 per cent. pilocarpine was found to cause a rapid miosis after syntropan-a significant point in the preferential use of this drug for examining the fundus of an eye suspected of glaucoma. It does not damage the corneal epithelium.

D. R. CAMPBEll.

(5) Nizetic, Z. (Belgrave).-Experience with cyclotropin in diseases of the anterior portion of the globe. (Erfahrungen mit Cyclotropin bei Erkrankungen des vorderen Bulbusabschnittes). Klin. Monatsbl. f. Augenheilk., Vol. XCVIII, p. 658, 1937.

(5) Nizetic gives the result of his experience of the use of cyclotropin in over 400 cases. The drug is made in 5 c.c. ampoules (Schering) and consists of $2.0 \mathrm{gm}$. urotropin, with $0.8 \mathrm{gm}$. sodium salicylate and $0.2 \mathrm{gm}$. caffeine-sodium salicylate. It has been demonstrated that urotropin soon appears in the aqueous humourwhether given per os or intravenously and that it breaks down into formaldehyde which persists for as long as 19 hours. Clinically, cyclotropin is of greatest value in cases of perforating injury where sympathetic inflammation has just begun and in all cases of cyclitis and iridocyclitis. It is best given intravenously, but it can also be given painlessly by intramuscular injection, if the more recent preparation of cyclotropin and novocaine be used. Two cases of herpetic inflammation gave good results, showing that cyclotropin has a good anti-infective action.

D. R. CAMPBell. 